\title{
Advances in the Neglected Chagas Disease: Drug Targets and Trypanocide Compounds
}

\author{
Vilma Gladys Duschak* \\ Department of Investigation, National Institute of Parasitology, Argentina
}

Submission: March 16, 2017; Published: July 31, 2017

*Corresponding author: Vilma Gladys Duschak, Department of Investigation, National Institute of Parasitology, ANLIS-Malbrán, Ministry of Health of the Nation, Argentina, Tel: +541143314010; Fax: +541143317142; E-mail: vduschak@conicet.gov.ar

\section{Opinion}

In the world of Biosciences, studies on neglected diseases must be taken into account. In this sense, Chagas disease, a parasitic infection commonly named American Trypanosomiasis affects millions of people all over Latin America. Presently, the number of international infected people estimated by the World Health Organization (WHO) amounts to 7 to 8 million and more than 10.000 deaths are assumed to happen yearly [1]. The disease has also emerged as a public health problematic elsewhere in non-endemic countries of the word due to transmission of etiologic agent, Trypanosoma cruzi by people migration [2,3]. Typically, it is spread by triatomine vectors. However, transmission also succeeds by organ transplantation or blood transfusion, from mother to newborn, and rarely due to eating or drinking contaminated aliments [4-8].

Notwithstanding, Chagas disease cannot be eradicated due to the presence of infected wild triatomines in unceasing contact with domestic cycles favoring the incidence of new cases, it could be likely to interrupt T. cruzi transmission in a vast region and to get rid of this disease as a public health problem with strong reduction in the burden of this disease [9]. Moreover, in this milieu, and regarding that there is no effective vaccine currently in rehearsal to combat this neglected disease, current chemotherapy is not suitable, is expensive and is still centered on the nitroaromatic compounds benznidazole and nifurtimox that provide both unsatisfactory results and substantially toxic side effects. So, the finding and investigation of novel ways to challenge this neglected disease is a key priority.

In addition, currently, once the disease has progressed to the chronic stage there is no effective drug. Furthermore, in the last years, children treatment was difficult due to the absence of these drugs in pediatric version. However, solid dispersions have been recently presented as alternative drug delivery system to improve the chemotherapy of Chagas disease and pediatric oral liquid suspension containing Benznidazole was easily prepared, being an interesting alternative for optimizing the pediatrictreatment of the disease $[10,11]$.

The advancement in the biologic and biochemical scientific knowledge of $T$. cruzi, in the last decades has increased the identification of multiple targets for Chagas' disease chemotherapy [12].Amid the best encouraging targets for trypanocidedrugs, ergosterol biosynthesis pathway [13] and cruzi pain [14], the major cysteine protease (CP) of T. cruzi, have been pointed out. Regrettably, recent clinical trials investigating the administration of pozoconazole and ravuconazole to chronic indeterminate Chagas disease patients revealed their lowliness compared to the standard drug Benznidazole [15].

In view of the information extended in the previous years and aimed to obtain more efficiency and less secondary effects, a rational approach for the fast development of new trypanocidal chemotherapy would be focused on K777, the cysteine proteinase inhibitor (CPI) near to enter to clinical trials, and founded on the clinical evaluation of combination of known drugs with existing anti-T. cruzi agents [16]. Besides, by using nuclear magnetic resonance spectroscopy, mapping of the inhibitor binding modes on the main active $\mathrm{Cz}$, was used for compounds screening aimed at fast evaluation of enzyme-inhibitor interactions, facilitating lead compounds identification followed by structural studies [17]. Recently, directed evolution in drug-sensitive yeast was addressed for the rapid discovery of Chagas disease drug targets [18].

On the other hand, top series of xanthine have been recently identified as clinical candidate for Chagas disease [19]. In addition, trypanothione biosynthesis, thiol-dependant redox and polyamine metabolism, the glycolytic, glyconeogenic, pentose phosphate, lipidic and polyisoprenoid biosynthetic pathways, and the enzymes from biosynthetic glycol conjugates pathways have been studied. Several specific enzymes from these biosynthetic pathways such as hypoxanthine-guanine- 
phosphoribosyl-transferase and farnesyl-pyrophosphate synthase, among others, have also been broadly studied in T. cruzi. Novel synthesized anti-T. cruzi compounds with or without specific single or multi-target assigned have been described in detail [12].Although the identification of new antiChagas disease agents is not only focused on target-based drug design and its derivatives and on synthetic or natural products screening [20] but also in old ones rediscovered as new drugs against Chagas disease [21-24], despite all the new data available, an appropriate drug has not been still identified.

In addition, the synergism of drugs such as $\mathrm{Nx}$ and buthionine sulfoximine has been demonstrated by in vitro and in vivo testing [24]. However, human research is required to ratify these results. Likewise, potential use of amiodarone and dronedarone was proposed [25]. Similar results could be expected with the combination of itraconazole and allopurinol [26], Bzand posaconazole [27], Bz and itraconazole [28], as well as Bzand all opurinol. The relevance of exploring the potential of the combination of treatments with currently available compounds to specifically treat Chagas diseasewas emphasized by the results obtained.

Currently despite some progress in preclinical studies has been developed, there is no yet an ideal drug or formulation for human treatment. A major problem in the evaluation of potential Chagas disease therapeutics is the lack of tools availability. Indeed, there is still an urgent need to discover a better biomarker capable to determine the efficacy of potential chemotherapeutics in treated patients [29]. Over the last few years, the Drugs for Neglected Diseases initiative (DNDi) has defined and implemented in collaboration with partners from the pharmaceutical industry, an early discovery strategy. It consists in a medium- to high- throughput phenotypic assay to accelerate the screening of compound libraries against kineto plastids, to identify a new class series for further development into preclinical candidates [19]. Unfortunately, trypanocide therapy with $\mathrm{Bz}$ in patients with established Chagas' cardiomyopathy significantly reduced serum parasite detection but did not significantly reduce cardiac clinical deterioration through 5 years of follow-up [30].

In conclusion, advances on anti-Chagas disease agents focused to specific parasite targets as their metabolic pathways or specific enzymes has been recently reviewed in detail [12]. Regarding all the data achieved in the last years, a rational approach for the fast advance of novel trypanocide chemotherapy would be focused on drugs ready to enter to clinical trials [31], on new scaffolds [32] and on the clinical evaluation of drug association with existing trypanocidal agents to get extra effectiveness and fewer secondary effects.

\section{References}

1. http://www.who.int/mediacentre/factsheets/fs340/en/

2. Gascon J, Bern C, Pinazo MJ (2010) Chagas disease in Spain, the United States and other non-endemic countries. Acta Trop 115(1-2): 22-27.
3. Perez-Molina JA, Norman F, Lopez-Velez R (2012) Chagas disease in non-endemic countries: Epidemiology, clinical presentationand treatment. Curr Infect Dis Rep 14(3): 263-274.

4. Benchimol Barbosa PR (2006) The oral transmission of Chagas disease: An acute form of infection responsible for regional outbreaks. Int J Cardiol 112: 132-133.

5. Bern C, Montgomery SP, Herwaldt BL (2007) Evaluation and treatment of Chagas disease in the United States: A systematic review. JAMA 298: 2171-2181.

6. Rassi A, Rassi A, Marcondes de Rezende J (2012) American trypanosomiasis (Chagas Disease). Infect Dis Clin North Am 26(2): 275-2791.

7. Sesti-Costa R, Silva JS, Gutierrez FR (2012) Congenital Chagas disease: Time to screen pregnant women? Expert Rev Anti Infect Ther 10(11): 1279-1282.

8. Kransdorf EP, Zakowski PC, Kobashigawa JA (2014) Chagas disease in solid organ and heart transplantation. CurrOpin Infect Dis 27(5): 418424.

9. Sosa-Estani S, Segura EL (2015) Integrated control of Chagas disease for its elimination as public health problem - A Review. Mem Inst Oswaldo Cruz 110(3): 289-298.

10. Fonseca-Berzal C, Palmeiro-Roldan R, Escario JA (2015) Novel solid dispersions of benznidazole: preparation, dissolutionprofile and biological evaluation as alternative antichagasic drug delivery system. ExpParasitol 149: 84-91.

11. Garcia MC, Manzo RH, Jimenez-Kairuz AF (2015) Extemporaneous benznidazole oral suspension prepared from commercially available tablets for treatment of Chagas disease in paediatricpatients. Trop Med Int Health 20(7): 864-870.

12. Targets and Patented Drugs for Chemotherapy of Chagas Disease in the Last 15 Years-Period (2016) Vilma Duschak, Recent Patents on AntiInfective Drug Discovery 11: 74-173.

13. Urbina JA (2009) Ergosterol biosynthesis and drug development for Chagas disease. Mem Inst Oswaldo Cruz 104(1): 311-318.

14. Duschak VG, Couto AS (2009) Cruzi pain, the major cysteine protease of Trypanosoma cruzi: a sulfated glycoprotein antigen as relevant candidate for vaccine development and drug target. A review.Curr Med Chem 16(24): 3174-202.

15. Urbina JA (2015) Recent clinical trials for the etiological treatment of chronic chagas disease: advances, challenges and perspectives. J Eukaryot Microbiol 62(1): 149-156.

16. McKerrow JH, Doyle PS, Engel JC, Podust LM, Robertson SA, et al. (2009) Two approaches to discovering and developing new drugs for Chagas disease. Mem Inst Oswaldo Cruz 104(1): 263-269.

17. Lee GM, Balouch E, Goetz DH, Lazic A, McKerrow JH, et al. (2012) Mapping inhibitor binding modes on an active cysteine protease via nuclear magnetic resonance spectroscopy. Biochemistry 51(50): 10087-10098.

18. Ottilie S, Goldgof GM, Calvet CM, Jennings GK, LaMonte G, et al. (2017) Rapid Chagas Disease Drug Target Discovery Using Directed Evolution in Drug-Sensitive Yeast.ACS Chem Biol 12(2): 422-434.

19. Neitz RJ, Chen S, Supek F, Yeh V, Kellar D, et al. (2015) Lead identification to clinical candidate selection: drugs for Chagas disease. J Biomol Screen 20(1): 101-111.

20. Duschak VG, Couto AS (2007) An insight on targets and patented drugs for chemotherapy of Chagas disease. Recent Pat AntiinfectDrug Discov 2(1): $19-51$.

21. Wiggers HJ, Rocha JR, Fernandes WB, Sesti-Costa R, Carneiro ZA, et al. (2013) Non-peptidiccruzain inhibitors with trypanocidal activity 


\section{Current Trends in Biomedical Engineering \& Biosciences}

discovered by virtual screening and in vitro assay. PLoS Negl Trop Dis $7(8):$ e2370.

22. Bellera CL, Balcazar DE, Alberca L, Labriola CA, Talevi A, et al. (2003) Application of computer-aided drug repurposingin the search of new cruzipain inhibitors: discovery of amiodarone and bromocriptine inhibitory effects. J ChemInfModel 53(9): 2402-248.

23. Avila JL, Avila A, Munoz E (1981) Effect of allopurinol on different strains of Trypanosoma cruzi. Am J Trop Med Hyg 30(4): 769-774.

24. Faundez M, Pino L, Letelier P, Ortiz C, López R, et al. (2005) Buthionine sulfoximineincreases the toxicity of nifurtimox and benznidazole to Trypanosomacruzi. Antimicrob Agents Chemother 49: 126-130.

25. Lepesheva GI (2013) Design or screening of drugs for the treatment of Chagas disease: what shows the most promise? Expert Opin Drug Discov 8(12): 1479-1489.

26. Apt W, Arribada A, Zulantay I, Solari A, Sánchez G, et al. (2005) Itraconazole or allopurinol in the treatment of chronic American trypanosomiasis: the results of clinical and parasitological examinations 11 years' post-treatment. Ann Trop Med Parasitol 99(8) 733-741.

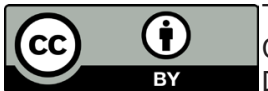

This work is licensed under Creative Commons Attribution 4.0 License DOI: 10.19080/CTBEB.2017.06.555693
27.Apt W (2010) Current and developing therapeutic agents in the treatment of Chagas disease. Drug Des Devel Ther 4: 243-253.

28. Assíria Fontes Martins T, de Figueiredo Diniz L, Mazzeti AL, da Silva do Nascimento ÁF, Caldas S et al. (2015) Benznidazole/itraconazole combination treatmentenhances anti-Trypanosoma cruziactivity in experimentalChagas Disease. PLoS One 10(6): e0128707.

29. Bahia MT, DinizLde F, Mosqueira VC (2014) Therapeutical approaches under investigation for treatment of Chagas disease. Expert OpinInvestig Drugs 23(9): 1225-1237.

30. Don R, Ioset JR (2014) Screening strategies to identify new chemical diversity for drug development to treat kinetoplastid infections. Parasitology 141(1): 140-146.

31. Morillo CA, Marin-Neto JA, Avezum S, Sosa-E, Rassi A, et al. (2015) Randomized trial of benznidazole for Chronic Chagas' Cardiomyopathy. N Engl J Med 373(14): 1295-1306.

32. Rhee SW, Bradford WW, Malerich JP, TangaMJ (2013) Carbon-14 labeling of $\mathrm{K} 777 \cdot \mathrm{HCl}$, a therapeutic agent for Chagas disease. J Labelled Comp Radiopharm 56(9-10): 461-463.

\section{Your next submission with Juniper Publishers}

will reach you the below assets

- Quality Editorial service

- Swift Peer Review

- Reprints availability

- E-prints Service

- Manuscript Podcast for convenient understanding

- Global attainment for your research

- Manuscript accessibility in different formats

( Pdf, E-pub, Full Text, Audio)

- Unceasing customer service

Track the below URL for one-step submission

https://juniperpublishers.com/online-submission.php 